\title{
Evaluation of P53 in the Expression of Odontogenic Keratocysts
}

\section{Bousserouit ${ }^{*}$ and S Chbicheb ${ }^{2}$}

${ }^{1}$ Resident, Department of Oral Surgery, Dental Center of Treatment and Diagnosis

(Ibn Sina Hospital), Rabat, Morocco

${ }^{2}$ Professor of Oral Surgery, Department of Oral Surgery, Faculty of Dentistry of

Rabat, Mohamed V University, Morocco

*Corresponding Author: M Bousserouit, Resident, Department of Oral Surgery,

Dental Center of Treatment and Diagnosis (Ibn Sina Hospital), Rabat, Morocco.
Received: June 15, 2020

Published: January 28, 2021

(C) All rights are reserved by $\mathbf{M}$ Bousserouit and $S$ Chbicheb.

DOI: $10.31080 /$ ASDS.2020.05.1028

\section{Introduction}

The odontogenic keratocyst also called epidermoid cyst, was first described by Philipsen in 1956; it develops at the expense of remnants of the odontogenic epithelium included in the maxillae. It is characterized by a large keratinization of its squamous border, aggressive growth and a strong propensity for recidivism. After the root cyst and the follicular cyst, the odontogenic keratocyst is the most common cyst of the maxillae.

The odontogenic keratocyst has been a widely studied pathology with a continually changing nomenclature of a "primordial cyst" to "odontogenic keratocyst". The aggressive nature of this unique jaw pathology has kept it in the limelight since its discovery with documented cases of cortical erosion, soft tissue involvement and extension in the skull base, orbit and infratemporal fossa. It's been a topic of debate for a long time, if the cysts could be as aggressive as this pathological entity.

\section{Materials and Methods}

Inclusion criteria

- Date of publication: from 2010 to 2019

- Language: French and English

- Population: Patients with odontogenic keratocysts

- The articles were analyzed according to the PICO methodology.

The population of the study
- Patients not suffering from general illness

- Patients with odontogenic keratocysts

The type of exploration

- Identification of the P53 protein using the polyclonal CM-1 antibody

- The standard technique of immunohistochemistry using monoclonal antibodies specific for P53.

The type of lesions

- Identification of P53 in root cysts and dentigian cysts, odontogenic keratocysts and calcifying odontogenic cysts (Gorlin cysts)

- Evaluation of P53 in benign tumors the expression of p53 in several types of odontogenic cystic lesions with and without dysplasia.

The type of keratinization

- The identification of the P53 protein in the odontogenic keratocyst orthokeratinizing and parakeratinizing.

\section{Discussion}

P53 is one of the most common tumor suppressor genes located on the short arm of chromosome 17 (Isobe., et al. 1986 and Ponten., et al. 2001). It is well recognized as a tumor suppressor gene $(\mathrm{Ku}-$ mamoto., et al. 2014). P53 is activated in cellular stresses, including DNA damage, hypoxia and nucleotide deprivation (Lakin., et al. 


\begin{tabular}{|c|c|c|c|c|c|}
\hline Title of the article & Authors & Review & $\begin{array}{c}\text { Release } \\
\text { date }\end{array}$ & Type & Goal \\
\hline $\begin{array}{l}\text { Markers of proliferation and } \\
\text { cytokeratins in the differential } \\
\text { diagnosis of jaw cysts }\end{array}$ & $\begin{array}{l}\text { Zivkovic., } \\
\quad \text { et al. }\end{array}$ & $\begin{array}{l}\text { Ear Nose and } \\
\text { Throat Journal } \\
\text { (ENT) }\end{array}$ & 2017 & $\begin{array}{l}\text { Retrospec- } \\
\text { tive study }\end{array}$ & $\begin{array}{l}\text { Analyze histological and } \\
\text { immunohistochemical results in } \\
\text { three main types of odontogenic } \\
\text { cyst }\end{array}$ \\
\hline $\begin{array}{l}\text { p53, p63 and p73 expression } \\
\text { and angiogenesis in keratocystic } \\
\text { odontogenic tumors }\end{array}$ & $\begin{array}{l}\text { Chandrang- } \\
\text { su., et al. }\end{array}$ & $\begin{array}{l}\text { Journal of } \\
\text { clinical and } \\
\text { experimental } \\
\text { dentistry }\end{array}$ & 2016 & In vitro & $\begin{array}{l}\text { The relationship between P53 } \\
\text { expression and angiogenesis and } \\
\text { recurrence of the keratocystic } \\
\text { tumor }\end{array}$ \\
\hline $\begin{array}{l}\text { Orthokeratinic odontogenic } \\
\text { keratocyst and keratocystic } \\
\text { odontogenic tumor: interest of } \\
\text { immunohistochemistry }\end{array}$ & Castro., et al. & $\begin{array}{l}\text { 64ème congrès } \\
\text { de la SFCO }\end{array}$ & 2016 & Case study & $\begin{array}{l}\text { Characterize the difference in } \\
\text { clinical and biological behavior } \\
\text { between the } 2 \text { forms. }\end{array}$ \\
\hline $\begin{array}{l}\text { The evaluation of Ki67, p53, } \\
\text { MCM3 and PCNA } \\
\text { immunoexpressions at the level } \\
\text { of the dental follicle } \\
\text { of impacted teeth, dentigerous } \\
\text { cysts and keratocystic odonto- } \\
\text { genic tumors }\end{array}$ & $\begin{array}{l}\text { Cosarca., } \\
\text { et al. }\end{array}$ & $\begin{array}{l}\text { Romanian } \\
\text { Journal of } \\
\text { Morphology } \\
\quad \text { and } \\
\text { Embryology }\end{array}$ & 2016 & In vitro & $\begin{array}{l}\text { Analyze the immunoexpression of } \\
\text { markers in keratocysts to evaluate } \\
\text { their evolutionary behavior }\end{array}$ \\
\hline $\begin{array}{l}\text { p53 and PCNA Expression } \\
\text { in Keratocystic Odontogenic } \\
\text { Tumors Compared with Selected } \\
\text { Odontogenic Cysts }\end{array}$ & $\begin{array}{l}\text { Seyedmajidi., } \\
\text { et al. }\end{array}$ & $\begin{array}{l}\text { International } \\
\text { Journal of } \\
\text { Molecular and } \\
\text { Cellular } \\
\text { Medicine ( } \\
\text { IJMCM) }\end{array}$ & 2013 & In vitro & $\begin{array}{l}\text { To evaluate the expression of p53 } \\
\text { and PCNA in different odontogenic } \\
\text { lesions concerning their different } \\
\text { clinical behaviors }\end{array}$ \\
\hline $\begin{array}{l}\text { Expansile keratocystic } \\
\text { odontogenic tumor in the } \\
\text { maxilla: immunohistochemical } \\
\text { studies and review of literature }\end{array}$ & $\begin{array}{c}\text { June-Ho } \\
\text { Byun., et al. }\end{array}$ & $\begin{array}{l}\text { Journal of } \\
\text { korean } \\
\text { association } \\
\text { of oral and } \\
\text { maxillofacial } \\
\text { surgery }\end{array}$ & 2013 & $\begin{array}{l}\text { Literature } \\
\text { review }\end{array}$ & $\begin{array}{l}\text { To evaluate the anti-apoptic activity } \\
\text { of keratocystic tumors by the } \\
\text { analysis of p53 }\end{array}$ \\
\hline
\end{tabular}




\begin{tabular}{|c|c|c|c|c|c|}
\hline $\begin{array}{l}\text { Primary intraosseous squamous } \\
\text { cell carcinoma arising in an } \\
\text { odontogenic keratocyst } \\
\text { previously treated with } \\
\text { marsupialization : case report } \\
\text { and immune-histochemical } \\
\text { study }\end{array}$ & $\begin{array}{l}\text { Tamgadge., } \\
\text { et al. }\end{array}$ & $\begin{array}{l}\text { Ecancer } \\
\text { medical } \\
\text { science }\end{array}$ & 2013 & Clinical case & $\begin{array}{l}\text { Immunohistochemical study on } \\
\text { epidermoid carcinoma occurring on } \\
\text { a keratocyst treated with } \\
\text { marsupialization }\end{array}$ \\
\hline $\begin{array}{l}\text { Immunohistochemical study } \\
\text { of proliferation factors (Ki67, } \\
\text { PCNA) and apoptosis (P53) on } \\
40 \text { odontogenic keratocysts }\end{array}$ & $\begin{array}{l}\text { Beltaief., et } \\
\text { al. }\end{array}$ & $\begin{array}{l}\text { Médecine } \\
\text { Buccale } \\
\text { Chirurgie } \\
\text { buccale }\end{array}$ & 2012 & $\begin{array}{l}\text { Retrospec- } \\
\text { tive study }\end{array}$ & $\begin{array}{l}\text { PCNA, Ki67 and P53 are not } \\
\text { markers for the histopronostic of } \\
\text { odontogenic keratocysts }\end{array}$ \\
\hline $\begin{array}{l}\text { Immunohistochemical } \\
\text { Comparison of the Expression } \\
\text { of p53 and MDM2 Proteins in } \\
\text { Ameloblastomas and } \\
\text { Keratocystic Odontogenic } \\
\text { Tumors }\end{array}$ & $\begin{array}{l}\text { Sharifi } \\
\text {-Sistani., et } \\
\text { al. }\end{array}$ & $\begin{array}{l}\text { Journal of } \\
\text { Craniofacial } \\
\text { surgery }\end{array}$ & 2011 & $\begin{array}{l}\text { Retrospec- } \\
\text { tive and } \\
\text { descriptive } \\
\text { study }\end{array}$ & $\begin{array}{l}\text { Compare the expression of MDM2 } \\
\text { and p53 in ameloblastoma and } \\
\text { keratotic odontogenic tumor as } 2 \\
\text { lesions with a similar biological } \\
\text { behavior, by immunohistochemistry }\end{array}$ \\
\hline $\begin{array}{l}\text { Immunohistochemical analysis } \\
\text { of P53 proteinin odontogenic } \\
\text { cysts }\end{array}$ & $\begin{array}{l}\text { Gaballah., } \\
\text { et al. }\end{array}$ & $\begin{array}{c}\text { The Saudi } \\
\text { Dental Journal }\end{array}$ & 2010 & In vitro & $\begin{array}{l}\text { To study the } \\
\text { immunohistochemical expression } \\
\text { of the P53 protein in odontogenic } \\
\text { cysts }\end{array}$ \\
\hline
\end{tabular}

Table 1: Descriptive table of the articles included in the study.

1999). In more than half of the tumors, there is a complete loss of p53 function on one allele coupled with complete inactivation of the other allele (Lane and 1999).

The disturbed function of P53 causes an uncontrolled proliferation of the cell. P53 mutations are present in more than $50 \%$ of malignancies and are commonly related to decreased cell differentiation and early recurrence (Hollstein., et al. 1994).

To answer the main objective: "To evaluate the expression of P53 in odontogenic keratocysts", our study looked at articles based on the analysis of biological markers including p53 in keratocysts and to evaluate their evolutionary character.

This analysis showed that the articles included in the journal included the following parameters

Staining area odontogenic keratocysts P53 and MDM2 (double minute murine 2): The highest staining area of the P53 was the suprabasal region of the odontogenic keratocysts, in fact the study conducted by Sharifi-Sistani in 2011 [1] on 15 paraffin-embedded keratocysts from the Department of Oral Pathology archives. and maxillofacial, from the Faculty of Dentistry, the University of Medical Sciences Mashhad and Quaem Hospital, which aimed to compare the expression of MDM2, an enhancer of cell proliferation and p53 by Immunohistochemistry, found increased expression of P53 in 100\% of keratocysts, these results are in agreement with the results of studies Ogden., et al. in 1999 [2], Slootweg in 1995 [3], Li., et al. in 1995 [4], Kichi., et al. In 2005 [5], Piatelli., et al. In 2001 [6] who found staining in intermediate, basal, and parabasal, suprabasal epithelial cells, respectively. However, Carvalhais., et al. in 1999 [7] found no increase in the p53 expression, which contradicts our results.

In the Oliveira., et al. study in 2008 [8], the percentage of p53positive cells was higher in the suprabasal layer of keratocysts, Gurgel., et al. in 2008 [9] also found a higher percentage of p53 and Ki-67 in the suprabasal layer. 
P53 and MDM2 are related to each other and act in the same direction: In these lesions when one increases, the other will do the same. MDM2 is increased in some tumors, but it is unable to decrease the amount of mutated p53 protein, and as p53 increases, MDM2 also increases. Therefore, increased expression of p53 and MDM2 proteins is likely to play a role in the pathogenesis and tumorigenesis of odontogenic keratocysts.

It is concluded that the high expression of P53 in the epithelial wall of keratocysts could mean a high proliferative activity of the epithelium leading to a high rate of recurrence or an increased incidence of development of neoplasms of the epithelial wall of keratocysts.

A study conducted by Seyedmajidi., et al. in 2013 [10] aimed at evaluating the expression of p53 and PCNA in different odontogenic lesions concerning their different clinical behaviors. The results of this study showed that the root cyst and keratocysts had a high percentage of p53 positive cells in their basal layer. In keratocysts, the suprabasal layer showed the highest expression of PCNA. These unique findings in keratocysts have shown that the proliferative components of this lesion are found in the basal and suprabasal layers. This discovery may justify the neoplastic nature of keratocysts and may also explain the clinical behavior and recurrent tendency of these lesions. These results are in contradiction with Carvalhai., et al. In 1999 [7] found no positive cell and Mighell., et al. Which justified the difference of results by the complex biology of p53 and PCNA, histological preparation and classification protocol. immunohistochemical used. Thus, the type of lesion, the etiology and the clinical behavior of the lesions must be taken into account. In addition, the strong expression of p53 in the basal radicular cystic layer indicates that inflammatory stimuli produced by persistent bacterial contamination of the root canal could induce cellular stress according to Oliveira., et al. in 2008 [8]. However, the authors did not declare any conflict of interest.

The relationship between P53 and the proliferative activity of lesions

The dental follicle is an ectomesenchymal tissue involved in the formation of periodontal components during the development of the tooth that is also present around the included teeth. Its structure may contain islands of persistent epithelial residues from the fragmentation of the tooth's blade, which can maintain their pro- liferative and differentiating capacity and can generate a pathology associated with dental inclusion. Most often, this pathology has cystic characteristics (dentigian cysts, odontogenic keratocysts ) but under certain circumstances, it can be transformed into tumoral processes (ameloblastoma) [11-13,28].

The term "odontogenic keratocyst" has created confusion in the past as it was considered a developmental cyst. Odontogenic keratocyst is currently considered a neoplastic lesion with an aggressive and progressive potential, a higher rate of recurrence and a specific histopathological appearance.

Although the importance of cell proliferation capacity from the epithelial remains of the dental follicles is not fully documented, the development of cystic and tumor lesions is closely related to these epithelial remains. The proliferation potential can be evaluated by immunohistochemical methods using specific markers for different stages of the cell cycle. The major protein involved in the regulation of the apoptotic process is $\mathrm{p} 53$.

A study by Cosarca., et al. in 2016 [14] included 20 cases of odontogenic keratocyst aimed at analyzing the immunoexpression of P53 in association with other biomarkers in the odontogenic epithelial remains of tooth follicles of teeth impacted to evaluate their proliferative capacity, as well as their potential for cystic transformation. Its objective was also to identify a possible correlation between the immunoexpression of markers studied in odontogenic keratocysts in order to evaluate their evolutionary behavior. This study was "born" because of the scarcity of information on this subject in the national and international literature.

Corsarca., et al. in 2016 [14] obtained a statistically significant correlation between p53 and other markers, which means that there is a close association between cell proliferation and apoptosis because the difference in median values in both layers is significantly higher for odontogenic keratocysts than for other cysts.

Shear., et al. in 2002 [15] and Nafarzaheh., et al. in 2013 [16] found that keratocysts, although benign tumors, their biological evolution is more aggressive, the development of this type of cyst was based on maintaining the proliferative capacity of cells in the parabasal layer which is in agreement with de Oliveira., et al. in 2008 and 2011 [8]. 
In a literature review conducted by June-Ho Byun., et al. in 2013 [17] P53 showed a strong expression compared to other proliferation markers, this indicates that the expandable keratocyst has increased anti-apoptotic activity and cell proliferation but reduced apoptosis. These keratocyst properties may contribute to tumor enlargement, aggressive behavior, and high rate of recurrence, because the P53 protein is expressed in the G1 phase of the cell cycle to allow repair of damaged DNA and to stop the tumor progression of the cell cycle to phase $S$.

These results are consistent with those of Lo Muzio., et al. in 2005 [18] and De Oliveira., et al. in 2008 [8]. However, Gadbail., et al. 2012 [19] confirmed that overexpression of P53 in odontogenic keratocysts and cysts may be associated with increased cell proliferation.

Furthermore, a descriptive analytical study by Razavi., et al. in 2014 (20) analyzed the clinicopathological and immunohistochemical features of primary and recurrent keratocysts, including the immunohistochemical expression of p53 protein in cystic epithelial cells in order to find more markers to predict specific behavior and a greater tendency to recurrence.

In this study, there were no statistically significant differences between primary and recurrent cases in terms of age $(P=0.181)$, sex $(P=0.744)$ and anatomical location $(P=0.294)$. The immunohistochemical staining for p53 shows a statistically significant difference between the two groups $(\mathrm{P}=0.041)$, which is consistent with the study conducted by Kuroyanagi., et al. in 2009 [21]. While in the studies conducted by Lombardi., et al. in 1995 and Gurgel., et al. in 2008 on p53 expression, there were no statistically significant differences between primary and recurrent keratocysts, and no correlation between expression and histopathological criteria, results that contradicted Razavi., et al. [20].

These results indicate that keratocysts may show different behaviors, the differences in the results being due to the benign nature of certain lesions. Other reasons may be technical problems in the immunohistochemical method adopted. However, the results of Razavi., et al. in 2014 [20] are similar to the results of the Kuroyanagi study which found strong expression of $\mathrm{p} 53$ protein in recurrent cases.
The effect of inflammation on the proliferative potential of lesions

The relationship between inflammation and cell proliferation in keratocysts was studied by Paula., et al. in 2000. They used AgNOR staining, Ki67 immunohistochemistry and PCNA for their analysis and concluded that the expression of biomarkers in this lesion showed a cell proliferation pattern compatible with neoplastic cells and independent of inflammation. The high levels of p53 and PCNA expression in the suprabasal layer may explain why keratocysts have a proliferation and maturation pattern that differs from other lesions. These results may explain its different clinical behaviors and the tendency to recurrence [22].

Kaplan and Hirschberg in 2004 studied areas with and without inflammation in keratocysts and found no significant difference in their proliferation rate. They concluded that the inflammation in odontogenic keratocyst. had no effect on its proliferative potential [23].

The expression of P53 in orthokeratinized and paraperatinized forms

Odontogenic keratocysts were described in 1956 by Philipsen., et al. [24]. They are characterized by the presence of a squamous, differentiated and keratinizing endocavitary epithelium. In 2005, the WHO differentiates keratocysts according to the type of keratinization. The orthokeratinized type is called odontogenic keratocyst orthokeratinising. The parakeratinized variant corresponds to the odontogenic keratocyst. This parakeratinized form is considered a benign tumor but has a local and recurrent aggressive potential.

The histological differential diagnosis can be difficult. There may indeed be inflammatory changes that tend to make keratinization disappear. The appearance of the basal layer and immunohistochemistry could provide additional elements for the diagnosis of these lesions.

Some biomarkers have been studied to characterize these lesions and to understand the difference in clinical and biological behavior between ortho and parakeratinized forms.

Thus, there is a significant increase in P53 expression in the suprabasal layers in parakeratinized odontogenic keratocysts compared to orthokeratinizing odontogenic keratocysts and oth- 
er odontogenic cysts (Deyhimi., et al. 2014). A mutation of P53 is observed in the parakeratinized odontogenic keratocyst (Gadbail, 2012).

The comparison of the expression of P53 in the different clinical forms did not show a statistically significant difference according to Beltaief., et al. in 2012 [25]. These results are consistent with what has already been published by Lombardi., et al. in 1995 [26], Li., et al. in 1996 [27], Piattelli., et al. in 2001 [6] and Gurgel in 2008 [9].

However, the expression of biological factors within a lesion and their use as cellular markers is a new and significant data that must be taken into consideration in establishing a positive diagnosis and monitoring of patients.

It is concluded that keratocysts generally exhibit high P53 expression in the basal and suprabasal layers in association with other biomarkers such as MDM2, PCNA, Ki-67. These results suggest a higher proliferative activity of the epithelial wall of odontogenic keratocysts leading to a high rate of recurrence or an increased incidence of development of neoplasms of their epithelial wall. Thus the presence of epithelial buds, odontogenic remains and daughter cysts in the connective tissue wall of odontogenic keratocysts is predictive of a greater tendency for recurrence.

By demonstrating the proliferative capacity of the dental follicle, we can affirm that the elimination of the included teeth can be considered in the prevention of a possible cyst or tumor transformation of the epithelial residues.

\section{Conclusion}

The results of our review confirm the more aggressive character of odontogenic keratocysts as documented in the literature and that certain inflammation factors have positive influences on the proliferative capacity of the odontogenic epithelium. In daily practice, in order to differentiate and evaluate the biological behavior of cystic lesions, the determination of immunoexpression of P53 and other markers for the parabasal and suprabasal basal layer is extremely useful.

\section{Bibliography}

1. Noorieh Sharifi-Sistani., et al. "Immunohistochemical Comparison of the Expressionof p53 and MDM2 Proteins in Ameloblas- tomasand Keratocystic Odontogenic Tumors". Journal of Craniofacial Surgery 22 (2011): 1652-1656.

2. Ogden GR., et al. "Assessment of p53 protein expression in normal, benign, and malignant oral mucosa". Journal of Pathology 166 (1992): 389-394.

3. Slootweg PJ. "P53 protein and Ki-67 reactivity in epithelial odontogenic lesions. An immunohistochemical study". Journal of Oral Pathology and Medicine 24 (1995): 393-397.

4. Li TJ., et al. "Epithelial cell proliferation in odontogenic keratocysts: a comparative immunocytochemical study of Ki67 in simple, recurrent and basal cell naevus syndrome (BCNS) Yassociated lesions". Journal of Oral Pathology and Medicine 24 (1995): 221-226.

5. Kichi E., et al. "Cell proliferation, apoptosis and apoptosisrelated factors in odontogenic keratocysts and in dentigerous cysts". Journal of Oral Pathology and Medicine 34 (2005): 280286.

6. Piattelli A., et al. "P53 protein expression in odontogenic cysts". Journal of Endodontics 27 (2001): 459-461.

7. Carvalhais J., et al. "P53 and MDM2 expression in odontogenic cysts and tumours". Oral Disease 5 (1999): 218-222.

8. de Oliveira MG., et al. "Immunohistochemical analysis of the patterns of p53 and PCNA expression in odontogenic cystic lesions". Medicina Oral, Patologia Oral y Cirugia Bucal 13 (2008): E275-E280

9. Gurgel CA., et al. "Expression of Ki-67, p53 and p63 proteins in keratocyst odontogenic tumours: an immunohistochemical study". Journal of Molecular Histology 39 (2008): 311-316.

10. Maryam Seyedmajidi., et al. "p53 and PCNA Expression in Keratocystic Odontogenic Tumors Compared with Selected Odontogenic Cysts". IJMCM Autumn 2.4 (2013).

11. Bath-Balogh M and Fehrenbach MJ. "Illustrated dental embryology, histology and anatomy". 3rd edition, Elsevier Saunders (2011): 50-61.

12. Borda A. "Curs de Histologie pentru Facultatea de Stomatologie". Vol. II, Universitatea de Medicină şi Farmacie din Tîrgu Mureş (2000): 40-90. 
13. Curran AE., et al. "Pathologically significant pericoronal lesions in adults: histopathologic evaluation". Journal of Oral and Maxillofacial Surgery 60.6 (2002): 613-617.

14. Adina-Simona Coşarcă., et al. "The evaluation of Ki67, p53, MCM3 and PCNA immunoexpressions at the level of the dental follicle of impacted teeth, dentigerous cysts and keratocystic odontogenic tumors". Romanian Journal of Morphology and Embryology 57.2 (2016): 407-412.

15. Shear M. "The aggressive nature of the odontogenic keratocyst: is it a benign cystic neoplasm? Part 2. Proliferation and genetic studies”. Oral Oncology 38.4 (2002): 323-331.

16. Nafarzadeh S., et al. "A comparative study of PCNA and Ki-67 expression in dental follicle, dentigerous cyst, unicystic ameloblastoma and ameloblastoma". International Journal of Molecular and Cellular Medicine 2.1 (2013): 27-33.

17. June-Ho Byun., et al. "Expansile keratocystic odontogenic tumor in the maxilla: immunohistochemical studies and review of literature". Journal of the Korean Association of Oral and Maxillofacial Surgeon 39 (2013): 182-187.

18. Lo Muzio L., et al. "p63 expression in odontogenic cysts". International Journal of Oral and Maxillofacial Surgery 34 (2005): 668-673.

19. Gadbail AR., et al. "Co-expression of Ki-67 and p53 protein in ameloblastoma and keratocystic odontogenic tumor". Acta Odontologica Scandinavica 70 (2012): 529-535.

20. Seyed Mohammad RAZAVI., et al. "Investigation of clinicopathological parameters alongside with p53 expression in primary and recurrent keratocystic odontogenic tumours". Malaysian Journal of Pathology 36.2 (2014): 105-113.

21. Kuroyanagi N., et al. "Prognostic factors for keratocystic odontogenic tumor (odontogenic keratocyst): analysis of clinicopathologic and immunohistochemical findings in cysts treated by enucleation". Journal of Oral Pathology and Medicine 38 (2009): 386-392.

22. de Paula AM., et al. "Cell proliferation markers in the odontogenic keratocyst: effect of inflammation". Journal of Oral Pathology and Medicine 29 (2000): 477-482.
23. Kaplan I and Hirshberg A. "The correlation between epithelial cell proliferation and inflammation in odontogenic keratocyst". Oral Oncology 40 (2004): 985-991.

24. Philipsen HP. "Om keratocyster (kolesteatom) I kaeberne". Tandlaege bladet 60 (1956): 963-981.

25. Ahlem Beltaief., et al. "Etude immunohistochimique des facteurs de la prolifération (Ki67, PCNA) et de l'apoptose (P53) sur 40 kératokystes odontogénes". Medecine Buccale Chirurgie Buccale 18 (2012): 17-22.

26. Lombardi T., et al. "p53 immunohistochemistry of odontogenic keratocysts in relation to recurrence, basal-cell budding and basal-cell naevus syndrome". Archives of Oral Biology 40.12 (1995): 1081-1084.

27. Li TJ., et al. "p53 expression in odontogenic keratocyst epithelium". Journal of Oral Pathology and Medicine 25.5 (1996): 249255.

28. Neville WB., et al. "Oral and maxillofacial pathology". 3rd edition, Elsevier Saunders, Philadelphia (2008).

\section{Assets from publication with us}

- Prompt Acknowledgement after receiving the article

- Thorough Double blinded peer review

- Rapid Publication

- Issue of Publication Certificate

- High visibility of your Published work

Website: www.actascientific.com/

Submit Article: www.actascientific.com/submission.php

Email us: editor@actascientific.com

Contact us: +919182824667 